\title{
CONSUMER OPINIONS ON THE CAUSES OF FOOD WASTE - DEMOGRAPHIC AND ECONOMIC CONDITIONS
}

\author{
OPINIE KONSUMENTÓW NA TEMAT PRZYCZYN MARNOTRAWIENIA ŻYWNOŚCI — \\ UWARUNKOWANIA DEMOGRAFICZNE I EKONOMICZNE
}

\section{Magdalena Ankiel}

Poznań University of Economics and Business, Institute of Marketing, Department of Product Marketing

al. Niepodległości 10, 61-875 Poznań, Poland

magdalena.ankiel@ue.poznan.pl O ORCID 0000-0003-2594-1600

\section{Urszula Samotyja}

Poznań University of Economics and Business, Institute of Quality Science, Department of Food Quality and Safety

al. Niepodległości 10, 61-875 Poznań, Poland

urszula.samotyja@ue.poznan.pl O ORCID 0000-0001-7388-0852

DOl: 10.2478/minib-2021-0022

\section{ABSTRACT}

Reducing the quantities of food lost or wasted will be an emerging challenge in coming years. The sector contributing the most to food waste is households. The aim of this study is to evaluate consumer behavior on the food market in the context of wastage identification and assessment of consumer opinions in Poland regarding the causes of the problem of food waste in households. A quantitative study was carried out using individual direct questionnaire interviews ( $N=1,145$ ). Results showed that Polish consumer opinions regarding reasons for wasting food vary according to demographic and economic conditions. The least educated consumers and families with several children were found to be guided by economic premises in their purchases more often than other groups and plan their purchases more rationally. The causes of food wastage related to irrational behavior were more often named by consumers with higher standards of living and by the younger generation.

Key words: consumer behavior; purchase decisions; food waste; consumer attitudes and opinions; sustainability 


\section{ABSTRAKT}

Zmniejszenie strat żywności stało się wyzwaniem na nadchodzące lata. Za marnotrawienie żywności w największym stopniu odpowiadają gospodarstwa domowe. Celem badania była ocena zachowań konsumentów na rynku żywności w kontekście identyfikacji marnotrawstwa oraz ocena opinii konsumentów w Polsce wobec przyczyn problemu marnowania żywności w gospodarstwach domowych. Badanie ilościowe przeprowadzono metodą indywidualnego bezpośredniego wywiadu kwestionariuszowego ( $\mathrm{N}=1145$ ). Wyniki wykazały, że opinie polskich konsumentów na temat przyczyn marnowania żywności są zróżnicowane w zależności od uwarunkowań demograficznych i ekonomicznych. Konsumenci z najniższym wykształceniem oraz wielodzietne rodziny częściej niż pozostali konsumenci kierują się przesłankami ekonomicznymi i bardziej racjonalnie planują zakupy. Przyczyny marnotrawienia żywności mające związek z nieracjonalnym zachowaniem były częściej wskazywane przez konsumentów o dobrym statusie materialnym oraz przedstawicieli młodego pokolenia.

Słowa kluczowe: Zachowanie konsumentów; Decyzje nabywcze; Marnotrawienie żywności; Postawy i opinie konsumentów; zrównoważony rozwój

JEL: D12, M31, D19

\section{Introduction}

The UN Food and Agriculture Organization (FAO) reports that one third of the world's food production ends up lost or wasted, which corresponds to 1.3 billion metric tons (FAO, 2019). The problem of food wastage occurs at all stages of the food supply chain, but the share varies in particular countries and depends on the GDP per capita. Decreasing the amount of edible food, mainly at the production stage, is characteristic of low-income countries, while developing countries struggle with the lack of technical facilities related to transportation and storage, as well as with low consumer awareness at the stage of handling and preparation of foodstuffs (Parfitt et al., 2010). These situations refer to what is called "food loss". In developed countries, food is lost mainly at retail and consumer levels, which 
is considered "food waste" (FAO, 2019). In the European Union countries, the sector contributing the most to food waste is households (47 million metric tons \pm 4 million metric tons), which account for $53 \%$ of the total mass of food wasted. This is equivalent to a mean value of 92 kilograms per person annually ( $\pm 9 \mathrm{~kg} /$ person/year), but the estimates vary in member states due to differing shares of household food waste. The costs associated with household food waste in the European Union have been estimated at around 98 billion euros per year (Fusions, 2016).

The most frequently reported reasons for household food wastage are lack of consumption at the right time, resulting in spoilage or expiration of food products (Aitsidou et al., 2019), food-related routines related to decisions in the food provisioning process (reuse of leftovers routines, planning routines and shopping routines), closely associated with the perceived skills of household members (Stancu et. al., 2016), poor stock management, and improper food storage (Lanfranchi et al., 2016). Consumers often feel confused by labels and do not understand the difference between various types of date labelling. This may result in throwing out safe and edible food products due to misunderstanding or excessive safety concerns (Wilson et al., 2017). The presence of competing goals, such as competition between health and food waste, competition between enjoyment and food waste, and between maintaining the budget and food waste, seems to have an impact on the intentions of consumers to reduce wastage (van Geffen et al., 2020). It was reported that low food prices do not motivate consumers to reduce food waste. Hungarian consumers admitted that they would need more money to reduce waste, arguing that it was often caused by low-quality food that spoils too fast.

The empirical evidence on the predictive power of socio-demographic factors is not clear. Earlier studies have reported a negative correlation between age and the amount of household food waste - young people have a greater propensity to waste food than elderly people (Karunasena et al., 2021; Bravi et al., 2020; Visschers et al., 2016; Quested et al., 2013; Secondi et al., 2015). The food waste behavior of younger generations is related to a lack of food management skills, for example the inability to plan their schedules due to extensive activities such as studies, work and social life (Ellison et al., 2019; Ghinea and Ghiuta, 2019). Young consumers found it 
difficult to identify appropriate portion size during food preparation (Bravi et al., 2020; Quested et al., 2013; Romani et al., 2018). The choice by young adults not to prepare shopping lists results in impulse buys, which also encourages household food waste behavior (Clark and Manning 2018). There is evidence that the younger generation's knowledge of how to proceed with food is low. Problems occur in deciding whether leftovers or outdated food are still safe to eat (Samotyja, 2021; Nikolaus et al., 2018). Millennials tend to regard date labels as food safety indicators instead of making a distinction between the "use by" and "best before" dates (Leib et al., 2016). According to Labuza et al. (2008), in the US in 2001 fewer people were able to identify correctly the meaning of the date labels on milk products than had been 20 years earlier. Contrary to young people, the $60+$ generation tend to have relatively high skill levels in food management, including the specific areas of preservation and the creative use of leftover ingredients (Visschers et al., 2016; Quested et al., 2013). Some researchers noticed that older consumers have more time and show high skill levels due to their involvement in food management around the home from an early stage of their lives (Conde-Caballero et al., 2021; Lanfranchi et al., 2016; Godfray et al., 2010). Additionally, personal experiences such as hunger or food insecurity are linked to concern about food waste (Karunasena et al. 2021). McAdams and von Massow (2018) stated that guilt was the unanimous feeling established in the childhoods of elderly consumers, associated with food waste. On the other hand, contradictory findings are also presented in the literature. Some authors argue that younger people are more concerned about the environment and thus more aware of the concept of food waste and less likely to waste food products (Grasso et al., 2019; Zepeda and Balaine, 2017) or that there is no significant relationship between age and the amount of food wasted in households (Falasconi et al., 2019).

There is also no agreement about the role of education in the amount of food wasted. In some studies, no significant influence was shown (Falasconi et al., 2019; Visschers et al., 2016; Stancu et al., 2016; Koivupuro et al., 2012). Hazuchova et al. (2020) reported that well 
educated consumers waste the least. In contradiction to this, other studies showed that consumers with higher education waste more food than less educated individuals (Secondi et al., 2015). This phenomenon is attributed to the higher income of better-educated people. According to the "food waste paradox", lower-income consumers may waste more food than their middle-class counterparts. In the literature, this phenomenon is explained by the previous experience of lower-income consumers with food deficit (Porpino et al., 2015), or the fact that they can simply afford to waste food (Secondi et al., 2015).

According to previous studies, the size of the household significantly affects the amount of food wasted in households. It was found that on a per capita basis, the amount of food waste decreases with the increasing number of people in the household, but, at the same time, larger households waste more food in total than smaller ones (Silvennoinen et al., 2014; Koivupuro et al., 2012). Visschers et al. (2016) stated that factors such as hou sehold size and children are fixed. Households with children waste more food because parents pay a lot of attention to food quality or experience difficulties in predicting the right amount of food needed (Visschers et al., 2016; Schanes et al., 2018). According to Grasso et al. (2019), the predictive value of the number of household members depends on the country and the average size of household.

The problem of consumer food waste is receiving increasing scientific attention. Previous studies greatly contributed to understanding the factors influencing consumer food waste and food waste behavior, but the results are not consistent and further work needs to be conducted regarding household food waste. A better understanding of the demographic and economic conditions that differentiate consumer opinions on the reasons for food waste is necessary. Alongside the scientific contribution, the findings of this study constitute a key issue for policymakers in order to implement effective preventive interventions. Therefore, the aim of this study was to evaluate consumer behavior on the food market in the context of wastage identification and assessment of consumer opinions in Poland on the causes of the problem of food waste in Polish households. 


\section{Materials and methods}

The empirical research on consumer behavior in the context of food waste was conducted by face-to-face interviews during the period from April to May 2019. The research tool was an interview questionnaire prepared and checked in piloting.

The quantitative study was carried out on consumer awareness of food labeling in the context of reducing food waste. One of the key research goals was to identify the behaviors and attitudes of individual consumers towards the problem of food waste in Poland, and in particular identification of consumers' opinions on the problem of food waste (particularly the causes of food waste in their opinion).

The research population was consumers declaring systematic purchase of food products. The selection of the research sample $(\mathrm{N}=1,145)$ was carried out by the quota method (selection criteria: sex, age, and place of residence), which met the demand for maintaining the relative representativeness of the research population. The survey was conducted by the authors. Data analysis was performed using the IBM SPSS Statistics tool.

\section{Results and Discussion}

The main issue in the study in the context of food waste by consumers in households in Poland was to diagnose the reasons for this. The consumers surveyed were asked to define what, in their opinion, were the key causes of food waste in households. The following reasons were given, and it was the consumers' responsibility to choose:

- lack of thought/planning in shopping,

- succumbing to the illusion of "excessive needs" when shopping,

- buying more just in case,

- it is normal that some of the products purchased are not used,

- smaller packages are not available,

- larger packages seem more cost-effective. 
The results of consumer opinions on the reasons for throwing out food are presented in Table 1.

\section{Table 1. The reasons for wasting food in the opinion of consumers in Poland (\%)}

\begin{tabular}{l|c}
\hline \multicolumn{1}{c|}{ Reasons for throwing out food } & Total* $^{*}$ \\
\hline lack of thought / planning in shopping & 51.0 \\
succumbing to the illusion of "excessive needs" when shopping & 37.0 \\
buying more just in case & 23.3 \\
larger packages seem more cost-effective & 13.8 \\
it is normal that some of the purchased products are not used & 11.1 \\
smaller packages are not available & 8.0 \\
\hline
\end{tabular}

* values do not add up to $100 \%$ due to the possibility of choosing several answers.

Consumers indicated that food in households in Poland is wasted mainly due to poorly planned purchases $(51.0 \%)$, which means that consumers buy products that are unnecessary. The second reason is the fact that during the purchasing process, consumers have the impression that their needs are much greater than they truly are, which also leads to buying excessive amounts of products (37.0\%). Another reason for wasting food is buying food products "just in case" (often for fear of a price increase in an era of inflation or a shortage of products, which was observable in the initial period of the Covid-19 pandemic). $13.8 \%$ of consumers indicated that the cause of food wastage is the purchase of large-packaged products (which seems to be more profitable), and $11.1 \%$ considered that food is wasted because it is normal for consumers not to consume all the products purchased. Only $8.0 \%$ of consumers believed that the cause of food waste was buying products in large packages (which means that the food is not consumed in its entirety), because small or standard packages are not available.

An interesting research issue is the assessment of the awareness and views of consumers in Poland on the causes of food waste depending on their level of education (Table 2). 


\section{Table 2. The reasons for wasting food in the opinion of consumers in Poland, and consumer education (\%)}

\begin{tabular}{l|c|c|c|c}
\hline \multirow{2}{*}{ Reasons for throwing out food } & \multicolumn{3}{c}{ Consumer education } \\
\cline { 2 - 5 } & $\begin{array}{c}\text { Vocational } \\
\text { education }\end{array}$ & $\begin{array}{c}\text { Secondary } \\
\text { education }\end{array}$ & $\begin{array}{c}\text { Bachelor's } \\
\text { degree }\end{array}$ & $\begin{array}{l}\text { Master's } \\
\text { degree }\end{array}$ \\
\hline lack of thought/planning in shopping & 44.3 & 50.7 & 56.4 & 50.6 \\
succumbing to the illusion of "excessive needs" when shopping & 30.3 & 34.2 & 40.7 & 42.5 \\
buying more just in case & 26.9 & 23.2 & 21.6 & 21.4 \\
it is normal that some of the purchased products are not used & 8.5 & 12.5 & 10.4 & 1.6 \\
smaller packages are not available & 8.0 & 10.1 & 7.1 & 6.6 \\
larger packages seem more cost-effective & 24.4 & 9.6 & 12.0 & 13.2 \\
\hline
\end{tabular}

The reason most frequently indicated by consumers for throwing away purchased food, i.e. "lack of thought / planning in shopping", occurs to the smallest extent among consumers with vocational education (44.3\%), and in consumer segments with higher education levels this percentage clearly increases and amounts to over $50.0 \%$ (the highest is in the group of people with engineering / undergraduate education - 56.4\%). It can be assumed that consumers with higher education are characterized by possessing greater awareness that the lack of planning in purchasing influences food wastage than consumers with vocational education, although this awareness does not increase proportionally. It can also be associated with the lower levels of income achieved by people with a lower level of education and the need to "save when shopping".

The relationship between "succumbing to the illusion of 'excessive needs' when shopping" and the education of the consumers in Poland surveyed clearly indicates that with the increase in the level of education, the percentage of consumers who identify this reason for throwing away food purchased increases. While in the segment of consumers with vocational education the percentage of consumers indicating that they are misled by excessive needs while shopping for food is $30.3 \%$, in the group of the most educated people this percentage is as high as 42.5\%, which is 12.2 percentage points higher. Thus, the more educated the consumer, the greater the awareness of the fact that when shopping, you are buying food that you do not really need, leading to non-consumption and ultimately the food being thrown out. 
On the other hand, when analyzing another cause of food wastage, i.e. "buying just in case", it can be concluded that in this case there is an opposite relationship than before; namely, the highest percentage of consumers indicating this cause occurs in the segment with the lowest education (26.9\%), and with the increase in the level of education, the percentage decreases (among people with higher education it is $21.4 \%$ ). Although the differences in the percentages of positive responses between consumers with vocational and graduate education are not significant, it can be assumed that with the increase in education, consumers indicate a smaller role for this factor.

Highly interesting results occur with the statement "it is normal that some of the purchased (food) products are not used". Both in the segment of consumers with vocational education, secondary and engineering/ /bachelor's this percentage fluctuates around 10.0\% (vocational $-8.5 \%$, secondary - 12.5, bachelor / engineering - 10.4\%), while in the segment of consumers with the highest level of education it is minimal and amounts to only $1.6 \%$. The above suggests that consumers with a master's degree are very aware that it is irrational not to use food purchased in its entirety, so people with lower education should be educated regarding the above.

When analyzing another indicated cause of food wastage in households in Poland, namely "larger packages seem more cost-effective", it can be seen that the highest percentage of consumers declaring this reason occurs in the segment of people with vocational education, and in the remaining segments this percentage clearly decreases (average - 9.6\%, bachelor/engineer - $12.0 \%$, master - 13.2\%). It can be assumed that people with vocational education are in the segment of economically sensitive consumers, with lower incomes than the segments of people with higher education, and therefore they buy food in larger than standard packaging due to the fact that the unit price is lower. Unfortunately, the consumers surveyed are aware that food that has not been purchased is not consumed in its entirety, which contributes to its wastage.

The results regarding the relationship between the last indicated reason for throwing away purchased food, i.e. "smaller packages are not available", and the education of the consumers surveyed indicate that there are no 
clear differences between the segments. The lowest percentage of indications is among people with a master's degree (6.6\%), and the highest among people with secondary education $(10.1 \%)$, so the difference is only 3.5 percentage points. To sum up, it can be stated that with increasing education, there is a decreasing percentage of consumers who declare that:

- food waste is caused by purchasing large packages of products (inexpensive) and ultimately by not consuming the entire food product;

- food waste is caused by purchasing it just in case and creating an excess that is not consumed.

On the other hand, with increasing education, there is a rising percentage of consumers who declare that:

- food waste is due to ill-considered/poorly planned shopping;

- food waste is caused by being influenced at the point of purchase, leading to the illusion of excessive needs and of buying food that is not really needed.

It can therefore be assumed that the least educated consumers more often than other segments are guided by economic premises in their purchases (purchasing large packages), plan their purchases more rationally (for savings reasons), but also buy in advance more often. On the other hand, consumers with the highest education (master's) believe that not consuming all of the purchased food is not a normal phenomenon and to a lesser extent they are driven by economic reasons (e.g. they are more often under the illusion of excessive needs when shopping and less often buy food in large packages). Thus, it can be concluded that the key reasons for wasting food in the segment of the least/most educated consumers in Poland are different.

In the context of consumer attitudes in Poland towards the problem of wasting purchased food, it is worth analyzing and assessing the relationship between consumer awareness of the causes of wastage and the level of income in the household (Table 3). 


\section{Table 3. The reasons for wasting food in the opinion of consumers in Poland, and the material status of the family (\%)}

\begin{tabular}{|c|c|c|c|c|c|}
\hline \multirow[b]{2}{*}{ Reasons for throwing out food } & \multicolumn{5}{|c|}{ Material status of the family } \\
\hline & $\begin{array}{l}\text { definitely } \\
\text { below the } \\
\text { national } \\
\text { average }\end{array}$ & $\begin{array}{c}\text { slightly } \\
\text { below the } \\
\text { national } \\
\text { average }\end{array}$ & $\begin{array}{c}\text { the } \\
\text { national } \\
\text { average }\end{array}$ & $\begin{array}{l}\text { slightly } \\
\text { above } \\
\text { the } \\
\text { national } \\
\text { average }\end{array}$ & $\begin{array}{c}\text { definitely } \\
\text { above } \\
\text { the } \\
\text { national } \\
\text { average }\end{array}$ \\
\hline lack of thought / planning in shopping & 51.6 & 48.0 & 53.6 & 50.9 & 49.7 \\
\hline $\begin{array}{l}\text { succumbing to the illusion of "excessive needs" } \\
\text { when shopping }\end{array}$ & 28.6 & 29.3 & 39.7 & 44.0 & 34.5 \\
\hline buying more just in case & 19.8 & 24.7 & 23.6 & 22.0 & 23.4 \\
\hline $\begin{array}{l}\text { it is normal that some of the purchased products } \\
\text { are not used }\end{array}$ & 11.0 & 13.6 & 9.5 & 9.9 & 13.1 \\
\hline smaller packages are not available & 13.2 & 10.6 & 6.2 & 6.2 & 9.7 \\
\hline larger packages seem more cost-effective & 18.7 & 12.6 & 13.8 & 15.0 & 11.0 \\
\hline
\end{tabular}

When analyzing the declarations of consumers that the reason for wasting food is "lack of thought/planning in purchasing" and the lack of planning in purchases with regard to the material status of their family, it can be observed that there are no significant differences in the percentages of indications within separate segments and they oscillate around 50.0\% (only in the segment of household with an average income is the ratio slightly higher, amounting to 53.6\%).

On the other hand, if it is stated that "we are under the illusion of 'excessive needs' while shopping", there are significant differences between the segments of consumers distinguished by the material status of the family. The lowest percentage of responses is in the segment of the poorest consumers, with the material status of the family definitely below (28.6\%) and slightly below the national average (29.3\%). In households with incomes at the level of the national average and above the national average, the percentage of consumers agreeing with this opinion on the causes of food waste clearly increases - it is the highest in the segment of consumers whose family material status is defined as "slightly above the national average" and amounts to as much as $44.0 \%$. 
Consumers agree to a similar extent, regardless of the material status of the family, with the statement "we buy more just in case", which contributes to food waste. The percentage of responses ranges from $19.8 \%$ in the segment of consumers describing the material status of their family as "definitely below the national average" to $24.7 \%$ in the segment of consumers describing the material status of their family as "slightly below the national average". It is evident that the difference is not significant and amounts to 4.9 percentage points. Thus, it can be concluded that in the case of this opinion on the problem of food waste, the material status of the family does not significantly differentiate consumer opinions. It is similar in the case of the statement: "it is normal that some of the purchased food products are not used" - the results presented in Table 3 show that there are no significant differences in the percentages of indications between consumer segments in terms of the differing material status of the family.

Considering the views of consumers on the causes of the problem of food wastage related to the purchase of large packages (which seem favorable in price or are purchased due to the lack of smaller food packages), it is observable that there are differences in the percentages of indications between consumer segments with different family material statuses. And so, in the case of the statement: "smaller packages are not available", the highest percentage occurs in the segment of consumers with a family material status definitely below the national average (13.2\%) and in the segment with material status slightly below the national average $(10.6 \%)$. On the other hand, the lowest percentage of responses, $6.2 \%$, is in the segment of consumers with an average familial financial status and slightly above the national average. Interestingly, in the segment of consumers from the best-off families (definitely above the national average) this percentage increases to $9.7 \%$. Thus, the notion that buying larger packages when smaller ones are not available contributes to food waste is more popular with consumers in the poorest segment and in the most affluent segment. On the other hand, in the case of the statement: "larger packages seem more cost-effective", the highest percentage of consumers agreeing with this opinion occurs in the segment of consumers who define the material status of their family much below the national average (18.7\%), and the lowest - in the segment of consumers who define their material status as definitely above the national average (11.0\%). 
In the remaining consumer segments, the ratio ranges from $12.6 \%$ (slightly below the national average), through $13.8 \%$ (national average) to $15.0 \%$ (slightly above the national average). Therefore, it can be assumed that consumers in Poland from the poorest households buy larger food packaging, while realizing that not consuming this food in its entirety contributes to its wastage.

Another interesting aspect of the study is the analysis of consumer attitudes in Poland towards the causes of food waste in Polish households depending on the age of consumers. The results are presented in Table 5.

\section{Table 5. The reasons for wasting food in the opinion of consumers in Poland, and the consumers' age (\%)}

\begin{tabular}{l|c|c|c|c|c|c}
\hline \multirow{2}{*}{ Reasons for throwing out food } & \multicolumn{7}{c}{ Consumers' age (years) } \\
\cline { 2 - 7 } & up to $\mathbf{1 9}$ & $\mathbf{2 0 - 2 9}$ & $\mathbf{3 0 - 3 9}$ & $\mathbf{4 0 - 4 9}$ & $\mathbf{5 0 - 5 9}$ & $\mathbf{6 0 +}$ \\
\hline lack of thought/planning in shopping & 48.0 & 57.1 & 49.8 & 49.3 & 53.0 & 47.7 \\
succumbing to the illusion of "excessive needs" & 32.0 & 42.9 & 40.4 & 38.7 & 36.3 & 31.5 \\
$\quad$ when shopping & & & & & & \\
buying more just in case & 16.0 & 18.9 & 20.4 & 25.3 & 26.2 & 26.0 \\
it is normal that some of the purchased & 20.0 & 12.2 & 10.7 & 10.0 & 8.9 & 11.5 \\
$\quad$ products are not used & & & & & & \\
smaller packages are not available & 0.0 & 6.6 & 8.9 & 7.3 & 7.1 & 9.6 \\
larger packages seem more cost-effective & 16.0 & 12.2 & 12.0 & 13.3 & 13.1 & 16.4 \\
\hline
\end{tabular}

The "lack of thought/planning in shopping" is indicated as the main reason for wasting food by the consumers surveyed, regardless of the age segment, although the highest percentage of indications occurs in the group of consumers aged 20-29 (57.1\%) and aged 50-59 years (53.0\%). On the other hand, "the illusion of 'excessive needs' when shopping", indicated as another important reason for wasting food, is most important for consumers aged 20-29 and 30-39, and least important for seniors 60+. Perhaps the elderly, due to their age and experience, limit the purchase of food products due to the feeling of excessive needs, while younger consumers do not have such long-established experiences and beliefs yet. Buying food "just in case" may contribute to its wastage mainly according to age-mature consumers, i.e. over 40 years of age. Analyzing the results of 
the study, it can be observed that as the age of consumers increases, the belief that buying food "in case" is an important factor leading to throwing away non-consumed food, and thus wasting it, increases. The belief that "it is normal that some of the purchased products are not used" is highest among the youngest consumers (up to 19 years) compared to other age groups. This is very worrying because such an attitude among young consumers may result in future purchasing and consumption decisions which will unfortunately lead to food waste. In turn, this reason is the least important for consumers aged 50-59. Analyzing another reason for wasting food in households, i.e. the belief that "larger packages seem more cost-effective" in the context of the age segments studied, it can be observed that there are slight differences in the indications by individual segments (they oscillate between $12.0 \%$ and 16.4\%). The "smaller packages are not available" is the last reason for food waste indicated by the surveyed consumers. Analyzing it through the prism of age segments, it can be seen that the youngest respondents (up to 19 years) did not indicate this reason at all (perhaps these consumers do not decide to buy food in larger packages when smaller ones are not available, and so this reason for food wastage is not relevant to them). On the other hand, the highest percentage of indications can be seen in the consumer segment of 30-39 years and $60+$.

The next correlation is the analysis of the relationship between the opinions of consumers in Poland about the causes of food waste and the size of the household. It is interesting to see whether consumers' views on the causes of wastage are different in small $(1,2)$, medium (3.4) and large (5+) households (they differ depending on the size of the household). The results obtained in the study are presented in Table 4.

Consumers from one and two-person households $(52.1 \%$ and $53.8 \%)$ and the largest $5+$ households $(54.4 \%)$ agree most with the statement that the cause of wasting food in households in Poland is "lack of thought / planning in shopping". In households of three and four people, the percentage of responses is lower and amounts to about $48 \%$. 


\section{Table 4. The reasons for wasting food in the opinion of consumers in Poland, and the number of people in the household (\%)}

\begin{tabular}{l|r|r|r|r|r}
\hline \multirow{2}{*}{ Reasons for throwing out food } & \multicolumn{5}{c}{ Number of persons in the household } \\
\cline { 2 - 5 } & $\mathbf{1}$ & $\mathbf{2}$ & $\mathbf{3}$ & $\mathbf{4}$ & $\mathbf{5 +}$ \\
\hline lack of thought / planning in shopping & 52.1 & 53.8 & 47.3 & 47.8 & 54.4 \\
succumbing to the illusion of "excessive needs" when shopping & 31.7 & 36.3 & 43.0 & 35.8 & 36.0 \\
buying more just in case & 21.1 & 23.4 & 25.3 & 25.7 & 16.7 \\
it is normal that some of the purchased products are not used & 13.4 & 8.5 & 13.1 & 12.8 & 8.8 \\
smaller packages are not available & 9.2 & 7.3 & 7.2 & 9.3 & 6.1 \\
larger packages seem more cost-effective & 10.6 & 14.6 & 11.4 & 12.8 & 19.3 \\
\hline
\end{tabular}

On the other hand, in the case of the opinion "succumbing to the illusion of 'excessive needs' when shopping", the lowest percentage of responses concerns consumers from one-person households (31.7\%), and the highest percentage from three-person households (43.0\%). In the case of consumers from two-person, four-person and the largest $5+$ households, the percentage of positive responses is practically the same and amounts to approximately $36 \%$. Thus, consumers from three-person households stand out from other segments due to a relatively high percentage of people indicating that being under the illusion of excessive needs while shopping is the reason for throwing away the purchased food.

When analyzing the statement "buying more just in case", depending on the size of the household, it can be observed that the segment of consumers from the largest households $(5+)$ least agree with this statement $(16.7 \%)$. In the remaining segments analyzed, the percentage of responses ranges from $21.1 \%$ (single-person households) to $25.7 \%$ (four-person households). Thus, it can be concluded that when analyzing the opinions of consumers regarding this cause of food waste in relation to the number of people in a household, only the most numerous households $(5+)$ with the lowest percentage of positive responses is distinguished. It can therefore be assumed that the largest households have the lowest tendency to engage in so-called "panic buying". However, this can also be associated with households that do make "larger" purchases entailing significant expense. 
If consumers agree with the statement that "it is normal that some of the products purchased are not used" in relation to the number of people in the household, it can be seen that the lowest percentage of consumers agreeing with the above is in the segment of two people $(8.5 \%)$ and $5+$ households $(8.8 \%)$. In the remaining segments, the percentage of indications hovers around $13.0 \%$. Therefore, no directly proportional relationship between the attitudes of consumers towards this cause of food wastage and the size of the household can be indicated.

On the other hand, when analyzing the opinions of consumers as to the statement: "it happens that smaller packages are not available" (which directly affects non-consumption and throwing away of food), it is interesting that the lowest percentage of indications occurs in the segment of the largest $5+$ households and amounts to only $6.1 \%$. Large households purchase larger quantities of products, so - perhaps - buying food in large packages is a standard purchase for them and does not involve the lack of consumption of the entire product, so it is the least considered cause of food waste.

However, different results are found in the case of the analysis of the last indicated cause of food waste, which is: "larger packages seem more cost-effective" depending on the size of the household. It turns out that consumers from one-person households (10.6\%) agree the least with this statement, and consumers from the largest 5+ households (19.3\%) most agree. Perhaps these indicators result from the specific purchasing decisions made by these households, namely individuals are less likely to buy large packages of food (although they may be cost-effective), because they will not have time to consume the product by the use by date. On the other hand, for households of $5+$, the purchase of food in large packages may be standard, and unfortunately this food is not always consumed, hence such a high percentage indicating this cause of food waste in Poland.

The last segmentation variable analyzed in the context of consumer attitudes and beliefs in Poland regarding the causes of food waste is the number of children in the household. The results of the study in this area are presented in Table 6. 


\section{Table 6. The reasons for wasting food in the opinion of consumers in Poland, and the number of children in the household (\%)}

\begin{tabular}{l|r|r|r|r|r}
\hline \multirow{2}{*}{\multicolumn{1}{c|}{ Reasons for throwing out food }} & \multicolumn{4}{|c}{ Number of children in the household } \\
\cline { 2 - 6 } & \multicolumn{1}{|c|}{$\mathbf{0}$} & $\mathbf{1}$ & $\mathbf{2}$ & $\mathbf{3}$ & $\mathbf{4 +}$ \\
\hline lack of thought/planning in shopping & 50.0 & 52.5 & 49.8 & 44.4 & 58.8 \\
succumbing to the illusion of "excessive needs" when shopping & 33.3 & 37.3 & 36.7 & 35.4 & 41.2 \\
buying more just in case & 25.0 & 22.4 & 27.0 & 24.2 & 16.2 \\
it is normal that some of the purchased products are not used & 16.7 & 10.9 & 10.1 & 14.6 & 4.4 \\
smaller packages are not available & 5.6 & 8.1 & 7.2 & 9.0 & 8.8 \\
larger packages seem to be more cost-effective & 13.9 & 13.0 & 13.5 & 15.2 & 19.1 \\
\hline
\end{tabular}

When analyzing consumers who indicate that the cause of food wastage is "lack of thought/planning in shopping" in terms of the number of children in households, it is evident that the highest percentage of indications occurs among consumers with 4 or more children in their family (58.8\%), and the lowest - among consumers with 3 children in the family (44.4\%). The above result is somewhat surprising, as it could be assumed that with the increase in the number of children, planning family purchases is rational and does not constitute a reason for wasting food, yet it turned out that there was no such relationship. On the other hand, in the case of the second most frequently mentioned reason by consumers which - in their opinion - contributes to food waste in households, i.e., "succumbing to the illusion of 'excessive needs' when shopping", the highest percentage occurs in families with 4 or more children $(41.2 \%)$, and the lowest in the case of families without any child (33.3\%). Perhaps families with many children, due to the number of children, actually experience excessive needs when shopping, which may affect their attitude towards the causes of food waste. On the other hand, these families indicate the least (among all analyzed segments) that the reason for throwing out food products is buying them "in case" (16.2\%). This may mean that such families have a limited household budget and they buy systematically, trying to avoid excessive stocks, which may limit food waste in their households. Also, when analyzing the attitudes of consumers towards the statement that "it 
is normal that some of the products purchased are not used" in relation to the number of children in a family, it can be noticed that consumers from families with the largest number of children least agree with this (4.4\%), while consumers from families without children agreed the most (16.7\%). Therefore, it can be assumed that families with many children make more rational purchases of food, which may contribute to limiting food wastage. Convincing consumers that buying food products in large packages contributes to wasting food because "larger packages seem more costeffective" is highest in the segment of consumers from the largest families (19.1\%), and lowest among consumers from small families. Thus, it can be seen that as the number of children in the family grows, the belief that purchasing large packages of products may contribute to non-consumption of all food, and thus its wastage, also grows. On the other hand, the attitudes of consumers towards the statement that buying products in large packages contributes to wasting food, as "the smaller packages are not available" can be considered independent of the number of children in the family.

Consumers in Poland admit that they did not consume the food purchased because they are not fully aware of the difficulties with interpreting the information on the shelf life of food. In the context of the above, an interesting research issue was to identify consumer opinions on the causes of food waste and to diagnose the relationship between opinions and segmentation variables such as consumer age, consumer education, material status, the number of people in the household and the number of children in the family (Ankiel \& Samotyja, 2020).

\section{Conclusions and recommendations}

Food wastage, both in Poland and worldwide, remains a key social, economic, behavioral and ethical problem. Consumers in Poland throw away food they do not consume for reasons related to poorly planned, excessive, impulse purchases, incorrect interpretation of various types of date labeling or buying food that they cannot properly prepare for consumption. Generally, our findings support the conclusion that Polish consumers consider the main cause of food waste to be "lack of 
thought/planning in shopping" and "the illusion of 'excessive needs' when shopping", while the lowest percentage of indications concerns the reason related to the purchase of food in large packages, namely: "smaller packages are not available" and "larger packages seem more costeffective". When analyzing the education of consumers in the context of the indicated reasons for wasting food, we found that less educated consumers more often indicated reasons related to the purchase of large packages or the belief that it is normal to always buy more. In turn, the most educated consumers more often indicated reasons based on the belief that they have greater consumption needs or that purchases are poorly planned. Taking into account the material status of consumers, consumers with a good standard of living pointed to the causes of food wastage related to irrational, impulse, and poorly planned purchases to a greater extent, while consumers with a poor standard of living pointed to the reasons related to the purchase of products in large packages (which may result from being guided by the economic determinants of the purchase). When analyzing the size of households (in terms of the number of people and the number of children in these households) in the context of the opinion on the causes of food wastage, our findings indicate that consumers from large households less frequently indicate the causes related to irrational purchasing behavior. Consumers from large households perceive the problem of "in case" purchases or those related to excessive needs to a lesser extent as the causes of food wastage in households, but more often indicate reasons related to the purchase of food in large packages.

Based on Polish consumers' opinions on the issue, therefore, we can conclude that reducing the problem of food wastage requires intensive education of consumers in the rational planning of food purchases, rational consumption, as well as the correct interpretation of food labeling with the terms of durability. In addition to the above, a significant role in preventing food wastage is played by food producers, who should, through communication activities, make consumers aware of the scale of the problem, but they should also clearly, reliably and legibly label food with durability terms so that the consumer has no problem reading and interpreting these. In addition, food producers should limit the packaging of food products with a short shelf life in large packages, as this favors the 
non-consumption of the entire product, and thus its wastage. Furthermore, it is worth mentioning the role of commercial entities (mainly large-format stores), which should conduct campaigns encouraging consumers to buy food products with a short shelf life (at a reduced price), as well as educational campaigns raising consumer awareness of the problem of food waste.

This study, conducted on the opinions/attitudes of consumers in Poland regarding the causes of food waste, has obvious limitations. These result from the declarative nature of the study, which does not necessarily reflect actual purchasing and consumption behavior. Nevertheless, the results and conclusions presented constitute valuable illustrative material concerning the attitudes of consumers towards the problem of food waste in Poland, which may form the basis for communication activities aimed at increasing public awareness and thus reducing the scale of waste.

\section{ACKNOWLEDGMENTS}

This study was supported by the National Science Centre (Narodowe Centrum Nauki), Poland [grant number 2017/27/B/HS4/00805].

\section{References}

1. Aitsidou, V., Michailidis, A., Partalidou M., \& Iakovidou, O. (2019). Household food waste management: socio-ecological dimensions. British Food Journal, 121(1): 2163-2178. https://doi.org/10.1108/BFJ-02-2019-0111.

2. Ankiel, M., \& Samotyja, U. (2020). The role of labels and perceived health risk in avoidable food wasting. Sustainability, 12(20):8725. https://doi.org/10.3390/su12208725.

3. Bravi, L., Francioni, B., Murmura, F., \& Savelli, E., (2020). Factors affecting household food waste among young consumers and actions to prevent it. A comparison among UK, Spain and Italy. Resources, Conservation \& Recycling. 153, 104586 https://doi.org/10.1016/j.resconrec.2019.104586.

4. Clark, J., \& Manning, L. (2018). What are the factors that an opportunity sample of UK students insinuate as being associated with their wastage of food in the home setting? Resources, Conservation \& Recycling. 130, 20-30. https://doi.org/10.1016/j.resconrec.2017.11.005.

5. Conde-Caballero, D., Rivero-Jimenez, B., \& Mariano-Juarez L. (2021). Memories of hunger, continuities, and food choices: An ethnography of the elderly in Extremadura (Spain) David. Appetite. 164, 105267. https://doi.org/10.1016/j.appet.2021.105267

6. Ellison, B., Savchenko, O., Nikolaus, C.J., \& Duff, B.R.L. (2019). Every plate counts: evaluation of a food waste reduction campaign in a university dining hall. Resources, Conservation \& Recycling. 144, 276-284. https://doi.org/10.1016/j.resconrec.2019.01.046.

7. Falasconi, L., Cicatiello, C., Franco, S., Segre, A., Setti, M., Vittuari, M. (2019). Such a shame! A study on self-perception of household food waste. Sustainability. 11(1), 270. https://doi.org/ $10.3390 /$ su11010270. 
8. FAO, (2019). The State of Food and Agriculture 2019. Moving forward on food loss and waste reduction. Food and Agriculture Organization of the United Nations. http://www.fao.org/publications/sofa/en/ (21.10.2021).

9. Fusions, (2016). Estimates of European food waste levels. IVL Swedish Environmental Research Institute. https://www.eu-fusions.org (10.11.2021).

10. Ghinea, C., \& Ghiuta, O.A. (2019). Household food waste generation: young consumers behaviour, habits and attitudes. International Journal of Environmental Science and Technology, 16(5), 2185-2200. https://doi.org/10.1007/s13762-018-1853-1.

11. Godfray, H.C.J., Beddington, J.R., Crute, I.R., Haddad, L., Lawrence, D., Muir, J.F., \& Toulmin, C. (2010). Food security: the challenge of feeding 9 billion people. Science. 327 (5967), 812-818. https://doi.org/10.1126/science.1185383.

12. Grasso, A.C., Olthof, M.R., Boevé, A.J., Van Dooren, C., Lähteenmäki, L., \& Brouwer, I.A. (2019). Socio-Demographic Predictors of Food Waste Behavior in Denmark and Spain. Sustainability, 11(12), 3244. https://doi.org/10.3390/su11123244.

13. Hazuchova, N., Antosova, I., \& Stavkova, J. (2020). Food Wastage as a Display of Consumer Behaviour. Journal of Competitiveness. 12(2), 51-66. https://doi.org/10.7441/joc.2020.02.04.

14. Karunasena, G.G., Ananda, J., \& Pearson D. (2021). Generational differences in food management skills and their impact on food waste in households. Resources, Conservation \& Recycling, 175, 105890. https://doi.org/10.1016/j.resconrec.2021.105890.

15. Koivupuro, H.K., Hartikainen, H., Silvennoinen, K., Katajajuuri, J.M., Heikintalo, N., Reinikainen, A., \& Jalkanen, L. (2012). Influence of socio-demographical, behavioural and attitudinal factors on the amount of avoidable food waste generated in Finnish households. International Journal of Consumer Studies. 36, 183-191. https://doi.org/10.1111/j.1470-6431.2011.01080.x

16. Labuza T.P., Szybis, L.M., \& Pec, J. (2008). Perishable Refrigerated Products and Home Practices Survey. In Open Dating of Foods. Trumbull, CT, USA: Food \& Nutrition Press, Inc.

17. Lanfranchi, M., Calabro, G., De Pascale, A., Fazio A., \& Giannetto C. (2016). Household food waste and eating behavior: empirical survey. British Food Journal, 118(12), 3059-3072. https://doi.org/10.1108/BFJ-01-2016-0001.

18. Leib E.B., Rice Ch., Neff R., Spiker M., Schklair A., \& Greenberg S. (2016). Consumer perceptions of date labels: National Survey. https://www.comunicarseweb.com/sites/default/files/consumerperceptions-on-date-labels_may-2016.pdf (02.11.2021).

19. Martindale W., \& Schiebel, W. (2017). The impact of food preservation on food waste, British Food Journal. 119, 2510-2518. https://doi.org/10.1108/BFJ-02-2017-0114.

20. McAdams, \& von Massow, M. (2018). Food Waste and Quality of Life in Elderly Populations Living in Retirement Living Communities. Journal of Housing for the Elderly, 33(1), 72-84. https://doi.org/10.1080/02763893.2018.1451801.

21. Nikolaus, C.J., Nickols-Richardson, S.M., \& Ellison, B. (2018). Wasted food: a qualitative study of U.S. young adults' perceptions, beliefs and behaviors. Appetite. 130, 70-78. https://doi.org/10.1016/j.appet.2018.07.026.

22. Parfitt, J.P., Barthel, M., \& Macnaughton, S. (2010). Food Waste within Food Supply Chains: Quantification and Potential for Change to 2050. Philosophical Transactions of the Royal Society Biological Sciences, 365, 3065-3081. https://doi.org/10.1098/rstb.2010.0126.

23. Porpino, G., Parente, J. G., \& Wansink, B. (2015). Food waste paradox: Antecedents of food disposal in low income households. International Journal of Consumer Studies. 39(6), 619-629. https://doi.org/10.1111/ijcs.12207.

24. Quested, T., Ingle, R. \& Parry, A. (2012). Final Report: Household Food and Drink Waste in the United Kingdom, WRAP. https://wrap.org.uk/resources/report/household-food-and-drink-wasteunited-kingdom-2012 (10.11.2021).

25. Romani, S., Grappi, S., Bagozzi, R.P., \& Barone, A.M. (2018). Domestic food practices: a study of food management behaviors and the role of food preparation planning in reducing waste. Appetite, 121, 215-227. https://doi.org/10.1016/j. appet.2017.11.093.

26. Samotyja U. (2021). The system of date labelling in the food supply chain - the weak links from the perspective of final consumers. Logforum. 17(3), 331-339. http://doi.org/10.17270/J.LOG.2021.600. 
27. Secondi, L., Principato, L., \& Laureti, T. (2015). Household food waste behaviour in EU-27 countries: A multilevel analysis. Food Policy, 56, 25-40. https://oi.org/10.1016/ j.foodpol.2015.07.007.

28. Silvennoinen, K., Katajajuuri, J.M., Hartikainen, H., Heikkilä, L., \& Reinikainen, A. (2014). Food waste volume and composition in Finnish households. British Food Journal, 116, 1058-1068. https://doi.org/10.1108/BFJ-12-2012-0311.

29. Stancu, V., Haugaard, P., \& Lähteenmäki, L. (2016). Determinants of consumer food waste behaviour: Two routes to food waste. Appetite, 96, 7-17. https://doi.org/10.1016/j.appet.2015.08.025.

30. van Geffen, L., van Herpen E., Sijtsema S., \& van Trijp H. (2020). Food waste as the consequence of competing motivations, lack of opportunities, and insufficient abilities. Resources, Conservation \& Recycling, X(5), 100026. https://doi.org 10.1016/j.rcrx.2019.100026.

31. Visschers, V.H.,Wickli, N., \& Siegrist, M. (2016). Sorting out food waste behaviour: A survey on the motivators and barriers of self-reported amounts of food waste in households. Journal of Environmental Psychology, 45, 66-78. https://doi.org/10.1016/j.jenvp.2015.11.007.

32. Williams, H., Lindström, A., Trischler, J., Wikström, F., \& Rowe, Z. (2020). Avoiding food becoming waste in households - The role of packaging in consumers' practices across different food categories. Journal of Cleaner Production, 265, 121775. https://doi.org/10.1016/ j.jclepro.2020.121775.

33. Wilson, N.L.W., Rickard, B.J., Saputo, R., \& Ho, S.T. (2017). Food waste: The role of date labels, package size, and product category. Food Quality and Preference, 55, 35-44. http://dx.doi.org/10.1016/j.foodqual.2016.08.004.

34. Zepeda, L., \& Balaine, L. (2017). Consumers' perceptions of food waste: a pilot study of U.S. students. International Journal of Consumer Studies, 41(6), 627-637. https://doi.org/10.1111/ijcs.12376.

35. Zhang, H., Duan, H., Andric, J.M., Song, M. \& Yang, B. (2018). Characterization of household food waste and strategies for its reduction: a Shenzhen City case study. Waste Management, 78, 426-433. 10.1016/j.wasman.2018.06.010.

Urszula Samotyja, Professor at the Poznań University of Economics and Business - She is employed in Food Quality and Safety Department of the Institute of Quality Science. Her research and teaching interests concern on the areas of shelf life of food, consumer understanding of shelf life labelling, food design and development, sensory assessments, food quality and safety and upgrading of food processing residues.

Magdalena Ankiel, Professor at the Poznan University of Economics and Business - She is head of Product Marketing Department at the Institute of Marketing. Her research and teaching interests concern on the areas of consumer behaviour, innovation design and development and informative value of packages. She is an author of several scientific papers and books. She has experience in product management and packaging innovation projects implemented for companies. 